\title{
Running the Obstacle Race towards Public Accounting Harmonization in EU-28: A Temporal Study
}

\author{
Vincenzo Sforza ${ }^{1} \&$ Riccardo Cimini ${ }^{1}$ \\ ${ }^{1}$ DEIM, University of Tuscia, Viterbo, Italy \\ Correspondence: University of Tuscia, Viterbo, Via Santa Maria in Gradi, 01100, Italy. E-mail: rcimini@unitus.it
}

Received: November 21, 2016

Accepted: January 11, 2017 Online Published: February 22, 2017

doi:10.5539/ijbm.v12n3p49

URL: https://doi.org/10.5539/ijbm.v12n3p49

\begin{abstract}
The European Commission has recently started a project aimed at harmonizing EU public accounting systems through the development of European Public Sector Accounting Standards (EPSAS). The project is a response to the lack of coherence between primary public-sector accounts and government financial statistics, in order to strengthen the economic governance structure in the euro area. This paper aims to show that the divergences (adjustments) between the measures of surplus/deficit in governmental (working balance, WB) and national accounting (net borrowing lending, NBL) vary over time to provide future research opportunities around the factors that, affecting temporal divergences between these measures, enhance fiscal fragility within the EU public sector accounting system. By analysing the Excessive Deficit Procedure (EDP) tables issued by 28 EU countries over the period 2010-2015, the paper uses novel approaches in measuring adjustments based on network analysis and regression models, showing that they are significantly different over time.
\end{abstract}

Keywords: comparative international governmental accounting, governmental sub-sectors, deficit/surplus measurement, accounting reforms, IPSAS-EPSAS, network analysis.

\section{Introduction}

The European Commission (2013) has recently launched a project for the establishment and implementation of European accounting standards for the public sector, the EPSAS. The sovereign debt crisis has certainly highlighted the need for more rigorous, transparent and comparable financial reporting by Member States.

A study prepared for Eurostat by Ernst and Young (EY, 2012) has provided evidence that the public accounting system and the related arrangements for auditing vary significantly between Member States and within different sub-sectors of government (EY, 2012, p. 1). According to the same study, different practices produce significant adjustments between the surplus/deficit measures (working balance, WB) calculated at micro-level by Member States following different accounting models - from cash to accrual - and the same one (net/borrowing lending, NBL) calculated at macro-level according to the ESA statistical framework, that records accounting flows on the accruals basis.

This paper belongs to the comparative international governmental accounting research (e.g., Chan and Jones, 1988) in the field of contributions that investigate the relationships between Governmental Accounting (micro-economic perspective) and National Accounting (macro-economic perspective). It aims to provide evidence that these adjustments vary over time considering all the different general government sub-sectors (e.g., central government, state government, local government, social security funds).

Its main motivations are twofold. First of all, scholars (Jesus and Jorge, 2012; Dasí et al., 2013; Jorge et al., 2014; Dasí et al., 2016; Jesus and Jorge, 2016; Sforza and Cimini, 2016) have mainly focused on the determinants of divergences at central government level, so it is of interest to enrich the analysis by widening the spectrum of investigation at all levels of government. Secondly, investigating the presence of any statistically significant differences regarding the temporal evolution of adjustments will provide new research opportunities around the factors that, more than others, affect such differences, being aware that these factors are not the only ones that affect the magnitude of adjustments within the governmental sub-sectors, since most of them are time invariant (e.g., basis for accounting the WB). For instance, dissimilarities among accounting practices and the fact that reforms are a long-date process should be the crucial factors that, more than others, affect the magnitude of total adjustments. 
To test the hypothesis that adjustments vary over time, the paper uses surplus/deficit data (the WB, the NBL and the magnitude of adjustments) tabulated in the EDP tables issued by 28 EU countries over the period 2010-2015, following the new ESA 2010 framework.

Compared with previous literature, this paper does something more. Focusing on all the sub-sectors of general government, it provides evidence, by following different methodologies, that adjustments vary over time.

As well as contributing to the literature, the paper has implications for all the institutions interested in obstructing the fragility of the surveillance system of EU fiscal policies. Such institutions should learn that a common high-quality set of accounting standards like the future EPSAS may not be able to completely fulfil the expectations for rigorous, transparent and comparable public accounts. This is due to the presence of factors that determine temporal differences among adjustments that standard setters cannot fully control. These include the adoption of a common strategy to implement accrual accounting within the sub-sector levels as well as the need for a cultural change that avoids "lacks of compliance" (Christiaens and Rommel, 2008).

The paper continues as follows. Section 2 is dedicated to the theoretical background and the development of the hypothesis. While section 3 describes the methodology adopted to test this hypothesis, the following sections 4 and 5 focus on the empirical findings and the discussion of the main results of this research. Finally, section 6 ends the paper with the limitations of the study and its possible future developments.

\section{Theoretical background and the development of the hypothesis}

Following the recent sovereign debt crisis, one of the most significant challenges towards strengthening EU governance and demonstrating financial stability is the implementation of accounting reforms aimed at improving the transparency, comparability and reliability of public accounts of Member States (European Commission, 2013). The inappropriateness of financial reporting in some EU member states - see the case of Greece - has highlighted the need for improved public sector management and governance in the euro area. The effectiveness of government expenditure policies, in terms of better macroeconomic performance (Abdullah et al., 2008; Lee, 2016) is highly dependent on the quality of the fiscal data used by countries.

The direction taken by countries in designing accounting reforms has been to move towards the adoption of accrual accounting. According to Lapsley et al. (2009), the empirical evidence available worldwide has shown that the "relentless advance" of the adoption of accrual accounting has often been driven, for legitimation purposes, by the need to demonstrate government effectiveness and efficiency. Furthermore, several studies, starting with the one conducted by Brignall and Modell (2000), have assumed that accounting reforms may have been implemented by public managers primarily in order to seek legitimacy rather than maximize efficiency. Without adequate preparation of the path towards change, this approach has led to an underestimation of the difficulties related to its implementation (Barton, 2009; Christiaens and Rommel, 2008; Hepworth, 2003; Lüder and Jones, 2003), which involves an impact on people (cultural change), processes (innovation and integration), institutions (organizational change), and so on.

For a long time now, literature has shown that the absence of a standardised global reference paradigm has led to the realization of accounting changes and, more generally, New Public Financial Management (NPFM) reforms with different development paths in different parts of the world (Guthrie and Humphrey, 1996; Olson et al., 1998).

In this direction, Council Directive 2011/85/EU obliged the European Commission to assess the suitability of the International Public Sector Accounting Standards (IPSAS) for Member States. This issue has also been discussed in accounting literature regarding improvements in transparency, accountability and comparability of financial reporting in the public sector (Brusca \& Hartinez, 2015; Brusca et al., 2013; Christiaens et al., 2010; Christiaens et al., 2014).

The European Commission's assessment was also supported by the answers given to a specific public consultation carried out by Eurostat between February and May 2012. It was considered inappropriate for the EU to adopt IPSAS directly and a decision was reached to develop specific European Public Sector Accounting Standards (EPSAS) to be designed with reference to the former. Among the documents that contain the main reasons for this decision, a comparative study (EY, 2012) prepared for Eurostat highlighted that, even though most Member States have already introduced accruals accounting systems, there is a substantial lack of coherence between primary public-sector accounts and ESA (European System of National and Regional Accounts) accruals data used for fiscal monitoring in the EU. The study revealed a wide variety of accounting models (basis of accounting, bookkeeping systems and practices) and auditing arrangements both between countries and the various levels of government within each country. 
The differences between Governmental Accounting and National Accounting is a relevant research area in public accounting, but, as noted by some academics - Brusca (2010), Dasí et al. (2013), Jorge et al. (2014) - it has not been the subject of much study. The works that have been conducted have mainly involved separate comparative analyses concerning central governments or local government entities.

Despite Jacobs and Cuganesan's (2014, p. 1252) call to go beyond descriptive studies, most have been conducted with qualitative methods (e.g. Dabbicco, 2013; Giovanelli, 2006; Keuning and Van Tongeren, 2004; Lüder, 2000; Montesinos and Vela, 2000; Martí, 2006), while Caperchione and Lapsley (2011, p. 103) noted the lack of empirical-quantitative studies.

With reference to quantitative studies, scholars have focused mostly on central governments, showing that one determinant of the difference between the WB (micro-economic perspective) and the NBL (macro-economic perspective) is the different basis followed by Member States to account for the former in respect to the latter.

Jesus and Jorge $(2012,2016)$ showed that cash-accrual adjustments are less significant and have lower impacts on the deficit/surplus in countries that report an accrual-based WB and are more significant in countries that follow the cash or mixed basis. In another research, Jorge et al. (2014) demonstrated that changing governmental accounting reporting basis into accruals reduces the materiality and diversity of the adjustments. The influence of the accrual basis of accounting is confirmed by the study by Dasí et al. (2013), who investigated the possible link between accounting adjustments and the administrative and accounting tradition of EU countries. These scholars have also found that not all the adjustments are due to the accounting basis for the WB, depending, for example, on the budgetary strategies of the different countries. In a subsequent study, Dasí et al. (2016) found that the transition from ESA95 to ESA 2010 has not shown any significant variation in the convergence/divergence between Governmental Accounting and National Accounting.

Also with reference to the central government level, Sforza and Cimini (2016) demonstrated that not only the basis for accounting the WB, but also the accounting practices at micro-level, affect the magnitude of adjustments, showing that the quality of enforcement (Nobes and Parker, 2010) is also a determinant of total adjustments in the extent to which it influences the accounting practices followed at micro-economic level for calculating the WB.

Few papers, if any, have studied simultaneously the reasons why adjustments are different in magnitude between all the general government sub-sectors: central government, state government, local government and social funds. Montesinos and Vela (2000) point out that the differences between national and governmental accounting will be partially phased out, standardizing the micro-accounting principles and financial practices in Europe, while those caused by different objectives and methodologies of the two kinds of systems should not be removed (see also Giovanelli, 2006).

The findings presented in the works by both practitioners and academics are extremely interesting and provide an opportunity to investigate the presence of any statistically-significant differences regarding the adjustments between Governmental Accounting and National Accounting over time. In fact, the analysis on the adjustments between Governmental and National accounts cannot be fully addressed without considering the time dimension. The accrual accounting adoption and, more generally, accounting changes are dynamic and long-term processes, which require a systemic approach that should cover not only the settlement of technical rules and the adaptation of IT systems, but also organizational change and development, process innovation and the cultural change of the actors involved in their implementation.

The literature has shown that accounting change may be studied from different angles (Liguori and Steccolini, 2014). Several researchers have investigated the process of accounting change using the institutional theory (see, for all, Burns and Scapens, 2000; Miller, 1994; Scapens, 1994). This perspective has allowed one to investigate the cultural influences on decision making and formal structures of organizations (Barley and Tolbert, 1997). It assumes that external pressures, constraints and expectations from institutional environments limit organizational choice, so organizations, in order to survive, must be responsive by adopting structures and practices consistent with external changes. According to the institutional perspective, and in particular to an "old" institutional economics (OIE) approach, Burns (2000, p. 572) has observed that "accounting practices and emerging routines can be said to be institutionalised when they become widely accepted in the organisation such that they become the unquestionable form of management control". Given that accounting change is the result of the interplay between new accounting practices, routines, institutions and power coalitions over time (Burns, 2000; Burns and Scapens, 2000), this phenomenon can only be studied by exploring the temporal dimensions of change.

The use of the concept of isomorphism under an institutional view (Kanter, 1972) opens up some interesting views for interpretation of the EU accounting reforms evolution. The framework proposed by DiMaggio and 
Powell (1983) is particularly useful regarding the types of pressures at the basis of the changes attributable to isomorphism: coercive, mimetic and normative. This framework, in its original or amended versions, has been taken into consideration in several studies aiming to investigate public sector accounting changes (Baker and Rennie, 2006; Christensen, 2005; Lande, 2006; Maingot, 2006; McSweeney and Duncan, 1998; Parker and Gould, 1999). Although, in practice, it is very difficult to draw clear distinctions between the three forms of isomorphism (Christensen, 2005; Czarniawska and Joerges, 1996; Modell, 2002), it is reasonable to assume that behind the various accounting reforms implemented by EU Member States, all three types of pressure are recognizable (e.g. for the case of France see Lande, 2006).

In most cases the reforms in a given country have been launched following a "step by step approach" (EY, 2012, p. 47), with different timing depending on the various levels of government, usually starting at local level. In this way, this level has developed experience that has proved useful for extending the reform to other levels of government. Or again, the public entities of a given level may have implemented a reform modelling themselves on the example of organizations perceived as more legitimate. So the isomorphistic view can also be useful in investigating the temporal dynamics analysis of adjustments between national and governmental accounting in EU Member States. Indeed, neglecting the dimension of time could lead to the risk of weakening the chances of success for the reforms. According to Christiaens and Rommel (2008), the empirical studies on governmental accounting reforms have often revealed that the design and implementation of reforms have appeared to be less successful than hoped for. The two scholars point out that many reforms have faced difficulties with a chronic "lack of compliance", manifesting problems as time progresses and obliging institutions to reform their previous reforms. In our case, for example, the chronic "lack of compliance" may be symptomatic of the variability of accounting practices with respect to different levels of governments, and their changes over time, accentuated, in all likelihood, by the need to review the previous reforms. An example is offered by the Italian public health-care organizations, which shifted from cash to accrual accounting from 1997 to 2001. This process was handled independently by each of the 20 regions in the country, without a common strategy. Until the entry into force of Legislative Decree 118/2011, which set out accounting harmonization for regions, local authorities and National Health Service organizations, the latter presented their financial reports using diversified structure, requirements and accounting principles, which were the subject of renovation over time by regional regulators. The latest accounting reforms have rolled out new financial statement schemes and uniform accounting principles to better ensure the comparability of annual reports, aiming to improve the process of consolidation of public finances. These arguments lead us to hypothesize that, while accounting reform is a long date process and accounting practices vary over time, the total adjustments disclosed in each governmental sub-sector should be different in magnitude over the period analysed. So, statistically significant temporal differences between total adjustments contribute to enhance fiscal fragility within the EU public sector accounting system.

\section{Methodological design}

To verify our hypothesis that adjustments vary over time, the EDP tables have been downloaded from the Eurostat website. The tables provided by each of the 28 EU Member States over the period 2010-2015 contain data which explains the transition between the national definitions of government balance and the deficit/surplus of each governmental sub-sector. In detail, Table $2 \mathrm{~A}$ discloses data concerning central government (CG), Table 2B data regarding state government (SG), Table $2 \mathrm{C}$ the local government (LG) and Table 2D the social security funds (SF). Comparison between such data is allowed despite the fact that the new ESA 2010 became effective in September 2014 because all the data has been restated following the rules of this new framework.

To test the hypothesis that there are temporal differences between total adjustments, this paper follows two alternative methodologies: the former is based on the use of networks and it is useful to test the existence of such differences; the latter is based on multivariate analysis and compares them testing whether they are statistically equivalent with each other.

For network analysis, using the Matlab ${ }^{\circledR}$ packages, we build a distance matrix with the temporal differences between total adjustments calculated for each governmental sub-sector. Probably, displaying the networks is the simplest methodology for detecting temporal divergences between adjustments, since it is well known that visual memory facilitates the human learning process and because pictures and graphs are more impressive than notes and/or numbers (Paivio, 1974).

For multivariate analysis, we compare temporal differences between total adjustments represented in the networks, using the following regression model, adopted by Sforza and Cimini (2016), that investigates the ability of the NBL to map the changes of the WB: 


$$
\mathrm{NBL}_{\mathrm{ct}}=\alpha_{0}+\alpha_{1} \mathrm{WB}_{\mathrm{ct}}+\varepsilon
$$

The term $\alpha_{1}$ is a coefficient that measures the ability of the NBL to map the change of the WB. It provides an idea about the magnitude of total adjustments. In fact, the more it is close to +1 the more total adjustments are not significant in magnitude, because any change of the WB is reflected in a change of the NBL of similar magnitude. The intercept $\alpha_{0}$ catches the other variables that affect the relationship between NBL and WB and is expected not to be statistically significant.

To verify whether temporal differences between total adjustments are statistically significant, we should detect the presence of structural breaks (Chow, 1960) in the regression coefficients that suggest the incremental capability of the NBL to map changes of the WB in the different years analysed. To do so, we implement the following regression model with interaction terms between $\mathrm{WB}$ and the $\mathrm{t}-1$ years analysed:

$$
\mathrm{NBL}_{\mathrm{ct}}=\alpha_{0}+\alpha_{1} \mathrm{WB}_{\mathrm{ct}}+\alpha_{i} \mathrm{Y}_{\mathrm{t}-1}+\alpha_{i} \mathrm{Y}_{\mathrm{t}-1} \mathrm{xWB} \mathrm{Ctc}_{1}+\varepsilon
$$

Where $\mathrm{Y}$ are dummies that control for the years analysed.

Our expectation is to find the coefficient of the interaction terms statistically significant. This suggests a different ability of the NBL to map changes of the WB over the period analysed. To test the presence of structural breaks with a Chow (1960) test, an F-test is performed to verify whether the interaction coefficients are statistically different from zero. Rejecting the null hypothesis (e.g. all the interaction coefficients are equal to zero) provides insights into the fact that NBL has a different ability to map changes of the WB over time and so that the temporal divergences of total adjustments are significant from a statistical point of view.

\section{Empirical Findings}

Our Table 1 reports, at a country-level, the total adjustments disclosed in each governmental sub-sector by the 28 European countries analysed over the period 2010-2015.

\begin{tabular}{|c|c|c|c|c|c|c|}
\hline M/euro & 2010 & 2011 & 2012 & 2013 & 2014 & 2015 \\
\hline AUSTRIA & $-3,465$ & $-3,261$ & 161 & -101 & $-5,125$ & $-2,212$ \\
\hline Central government & $-2,068$ & $-2,850$ & 60 & -353 & $-6,137$ & $-2,427$ \\
\hline State government & $-1,137$ & -535 & -21 & 131 & 814 & 18 \\
\hline Local government & -427 & -183 & -207 & -56 & -33 & -78 \\
\hline Social security funds & 167 & 307 & 329 & 177 & 231 & 275 \\
\hline BELGIUM & $-3,314$ & 1,330 & $-7,570$ & $-5,805$ & $-1,057$ & $-4,791$ \\
\hline Central government & -262 & 2,755 & $-5,491$ & $-2,173$ & 1,496 & 3,279 \\
\hline State government & -691 & 15 & 329 & -2195 & -545 & $-7,284$ \\
\hline Local government & $-1,568$ & $-1,262$ & $-1,249$ & -530 & $-1,201$ & -336 \\
\hline Social security funds & -793 & -178 & $-1,159$ & -907 & -807 & -450 \\
\hline BULGARIA & 276 & 201 & 536 & 716 & $-2,026$ & 436 \\
\hline Central government & 65 & 145 & 425 & 508 & $-2,151$ & 1,174 \\
\hline Local government & 188 & 39 & 159 & 260 & -97 & -652 \\
\hline Social security funds & 23 & 17 & -48 & -52 & 222 & -86 \\
\hline CROATIA & $-5,660$ & $-11,715$ & $-7,645$ & $-1,981$ & $-4,852$ & $-2,238$ \\
\hline Central government & $-5,593$ & $-11,228$ & $-6,655$ & $-2,793$ & $-6,405$ & $-1,847$ \\
\hline Local government & 14 & -75 & 115 & -684 & 717 & 57 \\
\hline Social security funds & -81 & -412 & $-1,105$ & 1,496 & 836 & -448 \\
\hline CYPRUS & 580 & -795 & $-1,015$ & $-1,680$ & $-1,740$ & -24 \\
\hline Central government & 569 & -806 & $-1,016$ & $-1,676$ & $-1,747$ & -28 \\
\hline Local government & -3 & 8 & 5 & 6 & 6 & 5 \\
\hline
\end{tabular}

Table 1. 


\begin{tabular}{|c|c|c|c|c|c|c|}
\hline Social security funds & 14 & 3 & -4 & -10 & 1 & -1 \\
\hline CZECH REPUBLIC & $-15,797$ & 52,675 & $-52,250$ & 10,500 & $-18,743$ & 27,769 \\
\hline Central government & 305 & 58,585 & $-48,608$ & 14,329 & $-12,484$ & 22,114 \\
\hline Local government & $-14,642$ & $-8,579$ & $-3,612$ & $-5,780$ & $-3,640$ & 3,797 \\
\hline Social security funds & $-1,460$ & 2,669 & -30 & 1,951 & $-2,619$ & 1,858 \\
\hline DENMARK & 42,366 & $-7,576$ & 10,675 & $-28,405$ & 18,732 & $-72,480$ \\
\hline Central government & 41,268 & $-7,559$ & 8,379 & $-30,407$ & 17,681 & $-71,955$ \\
\hline Local government & 1,760 & 811 & 2,867 & 2,380 & 1,492 & -210 \\
\hline Social security funds & -662 & -828 & -571 & -378 & -441 & -315 \\
\hline ESTONIA & -75.8 & 316 & -119 & -56.2 & 46.5 & 385.8 \\
\hline Central government & -95.5 & 304.1 & -81.5 & -37.7 & 51.6 & 369.2 \\
\hline Local government & 12.7 & 7.7 & -32.6 & -24.1 & -3.2 & 16.6 \\
\hline Social security funds & 7 & 4.2 & -4.9 & 5.6 & -1.9 & 0 \\
\hline FINLAND & 2,633 & 2,638 & 1,324 & 395 & $-2,387$ & $-2,840$ \\
\hline Central government & 644 & 815 & 376 & 841 & $-1,329$ & $-1,672$ \\
\hline Local government & $-3,433$ & $-3,605$ & $-3,925$ & $-4,161$ & $-4,447$ & $-3,948$ \\
\hline Social security funds & 5,422 & 5,428 & 4,873 & 3,715 & 3,389 & 2,780 \\
\hline FRANCE & 11,288 & $-25,747$ & $-26,875$ & $-24,507$ & $-13,406$ & $-23,906$ \\
\hline Central government & 37,951 & -699 & 2,968 & 6,674 & 13,169 & $-1,900$ \\
\hline Local government & $-31,501$ & $-33,029$ & $-34,574$ & $-37,708$ & $-31,828$ & $-27,008$ \\
\hline Social security funds & 4,838 & 7,981 & 4,731 & 6,527 & 5,253 & 5,002 \\
\hline GERMANY & $-28,023$ & $-18,818$ & 6,102 & 3,364 & 2,289 & -329 \\
\hline Central government & $-29,247$ & $-17,039$ & 3,667 & 5,173 & 4,962 & $-11,530$ \\
\hline State government & 179 & $-1,887$ & $-1,750$ & $-3,005$ & -822 & 2,266 \\
\hline Local government & 878 & 454 & 1,755 & 601 & $-2,174$ & 4,114 \\
\hline Social security funds & 167 & -346 & 2,430 & 595 & 323 & 4,821 \\
\hline GREECE & $-6,621$ & 1,811 & $-2,409$ & $-20,206$ & $-3,623$ & $-11,080$ \\
\hline Central government & $-4,644$ & 3,625 & -238 & $-22,164$ & $-4,115$ & $-9,184$ \\
\hline Local government & $-1,284$ & -311 & -312 & -360 & -682 & $-1,006$ \\
\hline Social security funds & -693 & $-1,503$ & $-1,859$ & 2,318 & 1,174 & -890 \\
\hline HUNGARY & $-62,001$ & 136,717 & $-153,977$ & 7,278 & 1,409 & 526,277 \\
\hline Central government & $-205,912$ & 0 & $-317,107$ & $-766,423$ & $-389,033$ & 515,764 \\
\hline Local government & 1,402 & 28,363 & 49,335 & 636,512 & 352,337 & $-18,461$ \\
\hline Social security funds & 142509 & 108354 & 113795 & 137,189 & 38,105 & 28,974 \\
\hline IRELAND & $-34,736$ & 3,109 & 904 & 1,335 & 978 & $-4,875$ \\
\hline Central government & $-34,807$ & 3,222 & 964 & 1,312 & 1,019 & $-5,564$ \\
\hline Local government & 71 & -113 & -60 & 23 & -41 & 689 \\
\hline Social security funds & 0 & 0 & 0 & 0 & 0 & 0 \\
\hline ITALY & 99 & 6,298 & 2,517 & 26,026 & 21,194 & 9,605 \\
\hline Central government & 1,837 & 5,569 & $-3,852$ & 30,496 & 22,449 & 13,444 \\
\hline Local government & $-6,468$ & $-2,457$ & 3,810 & $-6,611$ & $-2,906$ & $-6,111$ \\
\hline Social security funds & 4,730 & 3,186 & 2,559 & 2,141 & 1,651 & 2,272 \\
\hline LATVIA & 200 & 172.5 & -161.38 & -38.59 & -75.68 & -76.19 \\
\hline
\end{tabular}




\begin{tabular}{|c|c|c|c|c|c|c|}
\hline Central government & 314 & 209.29 & -212.49 & -37.95 & -97.23 & -138.7 \\
\hline Local government & -139 & -32.36 & 24.64 & 19.11 & 34.06 & 118.04 \\
\hline Social security funds & 25 & -4.43 & 26.47 & -19.75 & -12.51 & -55.53 \\
\hline LITHUANIA & 94 & -1.325 & -376 & -314 & 154 & 1.489 \\
\hline Central government & 341 & -1.304 & -351 & -275 & 289 & 1.320 \\
\hline Local government & -283 & -38 & -30 & -48 & 7 & 25 \\
\hline Social security funds & 36 & 17 & 5 & 9 & -142 & 144 \\
\hline LUXEMBOURG & -1.953 & 43 & -969 & -1.098 & -912 & 373 \\
\hline Central government & -1.848 & -358 & -697 & -858 & 61 & 6 \\
\hline Local government & 27 & 121 & 214 & 61 & 63 & 309 \\
\hline Social security funds & -132 & 280 & -486 & -301 & -1.036 & 58 \\
\hline MALTA & 59 & 40 & 83 & 23 & -43 & 102 \\
\hline Central government & 62 & 42 & 87 & 26 & -44 & 102 \\
\hline Local government & -3 & -2 & -4 & -3 & 1 & 0 \\
\hline THE NETHERLANDS & 1.259 & 143 & 5.980 & 1.133 & 1.856 & -20.250 \\
\hline Central government & 2.374 & 5.051 & 9.704 & 6.687 & 4.214 & -17.907 \\
\hline Local government & -6.962 & -4.392 & -4.081 & -4.589 & -3.204 & -4.334 \\
\hline Social security funds & 5.847 & -516 & 357 & -965 & 846 & 1.991 \\
\hline POLAND & -38.117 & -28.676 & -28.419 & -28.093 & -10.551 & 2.398 \\
\hline Central government & -33.602 & -25.564 & -25.021 & -23.195 & -7.532 & 7.376 \\
\hline Local government & -3.070 & -1.485 & -1.491 & -2.548 & -778 & -2.555 \\
\hline Social security funds & -1.445 & -1.627 & -1.907 & -2.350 & -2.241 & -2.423 \\
\hline PORTUGAL & -3.624 & 1.067 & 11.413 & 4.779 & 1.751 & 2.412 \\
\hline Central government & -2.966 & 676 & 9.581 & 3.726 & 935 & 2.138 \\
\hline Local government & -1.492 & -408 & 331 & 1.201 & 459 & 359 \\
\hline Social security funds & 834 & 799 & 1.501 & -148 & 357 & -85 \\
\hline ROMANIA & 400 & -5.372 & -2.487 & 4.834 & 13.275 & 13.211 \\
\hline Central government & 4.840 & 174 & -326 & 2.137 & 10.674 & 9.447 \\
\hline Local government & -3.174 & -4.258 & -1.867 & 5 & 1.829 & 2.704 \\
\hline Social security funds & -1.266 & -1.288 & -294 & 2.692 & 772 & 1.060 \\
\hline SLOVAK REPUBLIC & -342 & 97 & 395 & -235 & 890 & -869 \\
\hline Central government & 15 & 206 & 402 & 62 & 1039 & -344 \\
\hline Local government & -172 & -112 & 19 & 33 & -75 & 49 \\
\hline Social security funds & -185 & 3 & -26 & -330 & -74 & -574 \\
\hline SLOVENIA & -152 & -865 & -348 & -3.838 & -593 & 112 \\
\hline Central government & -107 & -924 & -285 & -3.875 & -690 & 3 \\
\hline Local government & 43 & 67 & 23 & -29 & 38 & 68 \\
\hline Social security funds & -88 & -8 & -86 & 66 & 59 & 41 \\
\hline SPAIN & -38.383 & -35.725 & -58.256 & -22.769 & -22.508 & -25.049 \\
\hline Central government & -12.572 & 4.714 & -60.780 & -16.021 & -18.149 & -21.371 \\
\hline State government & -17.043 & -30.408 & 6.975 & -1.175 & -1.695 & -18 \\
\hline Local government & -4.534 & -7.929 & -848 & -2.373 & -1.701 & -1.874 \\
\hline Social security funds & -4.234 & -2.102 & -3.603 & -3.200 & -963 & -1.786 \\
\hline
\end{tabular}




\begin{tabular}{lrrrrrr}
\hline SWEDEN & -86.463 & -55.696 & -114.417 & -33.915 & -130.138 & -26.358 \\
Central government & -13.746 & -79.752 & -15.236 & 86.584 & 22.767 & 28.473 \\
Local government & -11.800 & -17.988 & -23.482 & -15.638 & -29.956 & -17.005 \\
Social security funds & -60.917 & 42.044 & -75.699 & -104.861 & -122.949 & -37.826 \\
UNITED KINGDOM & 0 & 0 & 0 & 0 & 0 & 0 \\
Central government & 0 & 0 & 0 & 0 & 0 & 0 \\
Local government & 0 & 0 & 0 & 0 & 0 \\
EU 28 & $-269,472.8$ & $11,086.5$ & $-417,203.38$ & $-112,658.79$ & $-155,205.18$ & $387,192.61$ \\
\hline
\end{tabular}

The table provides evidence that at governmental-level, at country-level and considering the EU as a whole (e.g., EU 28), the magnitude of the total adjustments varies over time. Therefore, this table provides a first insight into the fact that the total adjustments disclosed in each governmental sub-sector should be different in magnitude over the period analysed.

The following Figure 1 displays the networks that provide evidence of the magnitude of temporal differences between total adjustments.

Figure 1.
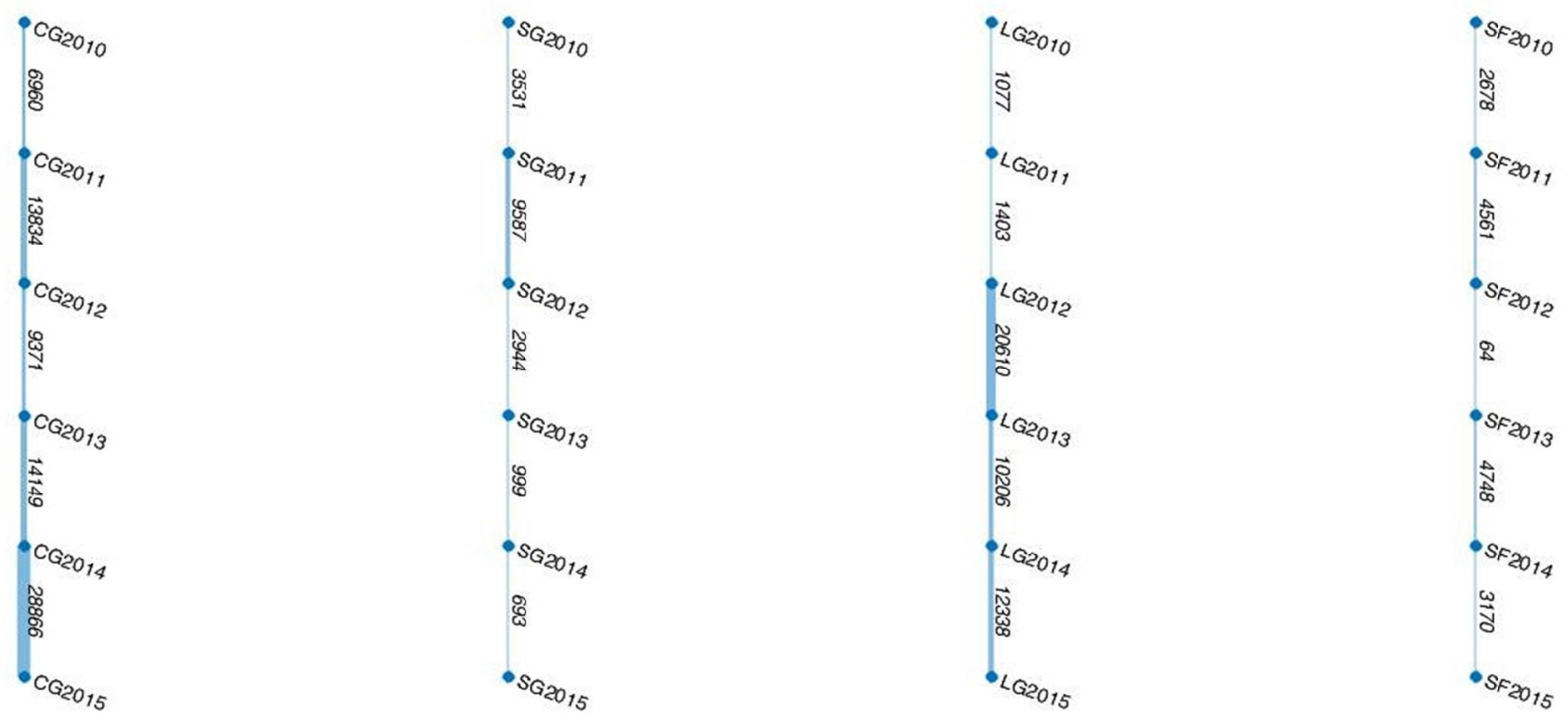

The picture shows 4 networks that represent the single governmental levels, that is, the central government (CG), the state government (SG), the local government (LG) and the social security funds (SF). For each network, six vertices represent the years (2010-2015) for which data has been collected. The thickness of the edges gives an idea about the magnitude of total adjustments in each node. Therefore, the thicker the edges, the more the temporal differences of adjustments are significant in magnitude. To provide a better idea about the differences of total adjustments between the different years analysed, the figure also shows the absolute value of the differences of total adjustments reported by each node. Our results suggest that total adjustments tend to be different over time, especially for central and local government. Following a random walk, their different magnitude over time provides further evidence of the need of harmonization against the fragility of EU fiscal policy. Fragility is not only due to the different bases for accounting the WB at micro-level, but also to the fact that total adjustments, following a "random walk" over time, are not persistent. 
Table 2 .

\begin{tabular}{|c|c|c|c|c|c|c|}
\hline$\alpha_{0}$ & Intercept & +1132.59 & +0.27 & & & \\
\hline$\alpha_{1}$ & $\mathrm{WB}_{\mathrm{ct}}$ & +1.18 & +27.09 & $* * *$ & N. of obs. & 516 \\
\hline$\alpha_{2}$ & $Y_{2011}$ & -1187.44 & -0.20 & & $\mathrm{~F}(11 ; 504)$ & $621.22 * * *$ \\
\hline$\alpha_{3}$ & $\mathrm{Y}_{2011} \mathrm{xWB} \mathrm{B}_{\mathrm{c} 2011}$ & -0.19 & -3.83 & $* * *$ & Prob $>F$ & 0.00 \\
\hline$\alpha_{4}$ & $\mathrm{Y}_{2012}$ & -146.20 & -0.02 & & R-squared & 0.93 \\
\hline$\alpha_{5}$ & $\mathrm{Y}_{2012} \mathrm{XWB}_{\mathrm{c} 2012}$ & +0.28 & +3.44 & $* * *$ & Adj R-squared & 0.93 \\
\hline$\alpha_{6}$ & $\mathrm{Y}_{2013}$ & +10144.04 & +1.74 & $*$ & \multicolumn{2}{|l|}{ Chow (1960) test: } \\
\hline$\alpha_{7}$ & $\mathrm{Y}_{2013} \mathrm{xWB} \mathrm{W}_{\mathrm{c} 2013}$ & +0.64 & +10.98 & $* * *$ & \multirow{2}{*}{\multicolumn{2}{|c|}{$\begin{array}{l}H_{0}: \text { structural stability of regression coefficients } \alpha_{2}-\alpha_{11} \\
F(10,504)=75.63 * * *\end{array}$}} \\
\hline$\alpha_{8}$ & $\mathrm{Y}_{2014}$ & +3034.79 & +0.52 & & & \\
\hline$\alpha_{9}$ & $\mathrm{Y}_{2014} \mathrm{XWB} \mathrm{B}_{\mathrm{c} 2014}$ & +0.28 & +4.53 & $* * *$ & & \\
\hline$\alpha_{10}$ & $Y_{2015}$ & -4045.29 & -0.69 & & & \\
\hline$\alpha_{11}$ & $\mathrm{Y}_{2015} \mathrm{xWB} \mathrm{B}_{\mathrm{c} 2015}$ & -0.61 & -11.40 & $* * *$ & & \\
\hline
\end{tabular}

(*) Value statistically significant at $10 \%,(* *)$ Value significant at $5 \%$ and $(* * *) 1 \%$.

The findings complete the results achieved using the network analysis, validating our expectation that the temporal differences between total adjustments are statistically significant. So, total adjustments diverge over time due to the different capability of the NBL to map changes of the WB over the different years analysed. This is suggested by the fact that all the interaction terms are statistically significant at $1 \%$ and the Chow (1960) for structural breaks rejects at $1 \%$ the null hypothesis that such interaction terms are equal to zero.

\section{Discussion}

The findings validate the hypothesis that total adjustments, and so the difference between the WB and the NBL do not remain unchanged but diverge over time. Now that evidence of temporal differences has been provided, it could be interesting to discuss which factors contribute more than others towards enhancing the variability of total adjustments and so the fragility of the surveillance system of EU fiscal policies.

In addition to the adjustments caused by different objectives and methodologies of the two kinds of systems (Giovanelli, 2006; Montesinos \& Vela, 2000), we could argue that differences between the years analysed could be explained largely in terms of accounting practices, which vary across years other than across general government sub-sectors. This consideration is consistent with the results of some empirical studies (EY, 2012, p. 22 ff.; PwC, 2014, p. 36) that, through the construction of a proximity indicator compared to some IPSAS, have shown the profound variety of accounting practices found in the various governmental sub-sectors of the EU member countries.

To understand how accounting practices influence the magnitude of adjustments, we can assume that two Member States follow the cash basis at the micro-economic level. The first records loan assets granted by the government to debtors as outflow in the WB; the second records them separately. If so, in the EDP tables the adjustments of the first country will be higher than those of the second country because of the financial transactions included in the WB. Therefore, the use of the cash basis shows how, in addition to depending on the basis of accounting, the magnitude of adjustments also depends on practices, which in our example involves presentation matters used at the micro-level to assess the WB. A further example concerns the manner in which low interest rate loans granted by a government are registered at micro-level. While at macro-level the interest has to be recorded on the basis of the contractually-agreed interest rate, if at micro-level different accounting practices are followed (Eurostat, 2013a; 2013b), the magnitude of total adjustments disclosed in the EDP tables increases.

From these examples we could learn that important divergences in accounting practices could justify the differences between total adjustments shown in our Table 1 and drawn in the networks of Figure 1. The same practices could also justify the presence of structural breaks of the regression coefficients disclosed in our Table 2.

Therefore, adjustments do not depend solely on the basis used to account the WB but also on other factors that involve the accounting practices followed at micro-level to assess it. The quality of legal enforcement could control these accounting practices. Actually, several authoritative scholars (Nobes and Parker, 2010; Kvaal and 
Nobes, 2010, 2012) have pointed out that in the European Union, despite the use of a common set of accounting standards, both motivations and opportunities for different accounting practices still exist. In detail, according to Nobes and Parker (2010), the motivations for different accounting practices include the differences in legal enforcement of countries. This is the reason why a measure of the quality of the legal system (enforcement) could be useful in controlling these practices. If our reasoning is correct, over time, total adjustments in EU countries with high-quality enforcement should vary at a lower rate than in countries with low-quality enforcement. Regardless of the basis for accounting the WB, where enforcement is weak, accounting practices could lead to a reduction in the quality of statistics at micro-level that makes the risk of both opportunistic forms of behaviour and/or unintentional mistakes (Ronen, 2008; 2012) more probable, that produce an increase in total adjustments. High-quality enforcement could reduce the magnitude of adjustments disclosed in the EDP tables because it obstructs the risk of both opportunistic forms of behaviour and unintentional mistakes also through a more effective system of sanctions. To provide a plausible explanation for our results that total adjustments assume a random walk over time, following Sforza and Cimini (2016), we calculate an index that controls the quality of the legal system moving from the World Bank indicators. Splitting this indicator at the median, EU countries have been clustered into two groups. In the former there are those with high-quality enforcement; in the latter there are those with low-quality enforcement. Calculating the standard deviation of total adjustments over time, we noticed that in countries with high-quality legal systems, total adjustments vary at a lower level than in countries with low-quality legal system. This is true for the central government, the state government and local government. In social funds we found opposite results. We can consider these findings consistent with those of Pina et al. (2007, p. 583) according to which developments and changes in financial accountability levels depend on both the context and characteristics of public administration styles and on how information is disclosed.

\section{Conclusions}

Accounting literature has demonstrated that one of the factors that affects EU fiscal fragility is the divergence between the different measures of deficit/surplus due to divergences in the basis followed to assess them. This paper adds to the literature showing that also the property of total adjustments varies over time and following a random walk enhances such fragility. The former (e.g. the different basis for accounting the WB that goes from cash to accrual) enhances divergences between countries; the latter (e.g., accounting practices) also has a multiplicative effect over time. If so, probably, a common high-quality set of accounting standards will not completely fulfil the expectations for rigorous, transparent and comparable public accounts, because most of the factors that contribute to increase fiscal fragility go beyond the accounting dimension. Therefore, accounting and auditing standards could have a crucial role in harmonizing the EU public accounting system, but, as far as we are concerned, they only guarantee a minimum degree of harmonization, homologating the basis for accounting the WB at micro-level or introducing a common set of auditing standards within the institutions included in the governmental sub-sectors. For the maximum degree of harmonization, such standards should also be accompanied by a cultural change that should lead the public accountant to grasp such changes and to comply with them. This will avoid reforms appearing to be less successful than hoped over time, or politicians having to face the problem that, after the introduction of reforms, the governmental levels are at different stages depending on how they have been introduced. In this regard, future research could test whether the magnitude of adjustments is affected by cultural variables that, according to Christiaens and Rommel (2008, p. 11), could have a key role in obstructing the fragility of a public accounting system.

\section{References}

Abdullah, H., Habibullah, M. S., \& Baharumshah, A. Z. (2008). Fiscal Policy, Institutions and Economic Growth in Asian Economies: Evidence from the Pedroni's Cointegration Approach. International Journal of Business and Management, 3(4), 107-126.

Baker, R., \& Rennie, M. D. (2006). Forces Leading to the Adoption of Accrual Accounting by the Canadian Federal Government: An Institutional Perspective. Canadian Accounting Perspectives, 5(1), 83-112. https://doi.org/10.1506/206K-RV7L-2JMN-W3D3

Barley, S. R., \& Tolbert, P. S. (1997). Institutionalization and structuration: Studying the links between action and institution. Organizations Studies, 18(1), 93-117. https://doi.org/10.1177/017084069701800106

Barton, A. (2009). The use and abuse of accounting in the public sector financial management reform program in Australia. Abacus, 45(2), 221-248. https://doi.org/10.1111/j.1467-6281.2009.00283.x

Brignall, S., \& Modell, S. (2000). An institutional perspective on performance measurement and management in the 'new public sector'. Management accounting research, 11(3), 281-306. 
https://doi.org/10.1006/mare.2000.0136

Brusca, I. (2010). Treinta años de investigación en contabilidad y gestión pública en España, Revista de contabilidad, 13(2), 175-209.

Brusca, I., \& Martínez, J. C. (2015). Adopting International Public Sector Accounting Standards: A challenge for modernizing and harmonizing public sector accounting. International Review of Administrative Sciences, $1-21$.

Brusca, I., Montesinos, V., \& Chow, D. S. (2013). Legitimating international public sector accounting standards (IPSAS): The case of Spain. Public Money \& Management, 33(6), 437-444. https://doi.org/10.1080/09540962.2013.836006

Burns, J. (2000). The dynamics of accounting change. Inter-play between new practices, routines, institutions, power and politics. Accounting, Auditing \& Accountability Journal, 13(5), 566-596. https://doi.org/10.1108/09513570010353710

Burns, J., \& Scapens, R. W. (2000). Conceptualizing management accounting change: an institutional framework. Management Accounting Research, 11, 3-25. https://doi.org/10.1006/mare.1999.0119

Caperchione, E., \& Lapsley, I. (2011). Making Comparisons in Government Accounting. Financial Accountability \& Management, 27(2), 103-106. https://doi.org/10.1111/j.1468-0408.2011.00518.x

Chan, J. L., \& Jones, R. H. (1988). Governmental Accounting and Auditing: International Comparisons (Routledge).

Chow, G. C. (1960). Tests of equality between sets of coefficients in two linear regressions. Econometrica, 28(3), 591-605. https://doi.org/10.2307/1910133

Christensen, M. (2005). The 'Third Hand': Private Sector Consultants in Public Sector Accounting Change. European Accounting Review, 14(3), 447-474. https://doi.org/10.1080/0963818042000306217

Christiaens, J., \& Rommel, J. (2008). Accrual accounting reforms: only for businesslike (parts of) governments. Financial Accountability \& Management, 24(1), 59-75. https://doi.org/10.1111/j.1468-0408.2008.00443.x

Christiaens, J., Reyniers, B., \& Rollé, C. (2010). Impact of IPSAS on reforming governmental financial information systems: a comparative study. International Review of Administrative Sciences, 76(3), 537-554. https://doi.org/10.1177/0020852310372449

Christiaens, J., Vanhee, C., Manes-Rossi, F., Aversano, N., \& Van Cauwenberge, P. (2014). The effect of IPSAS on reforming governmental financial reporting: An international comparison. International Review of Administrative Sciences, 1-20.

Czarniawska, B., \& Joerges, B. (1996). Travel of ideas. In Czarniawska B. \& Joerges B. (Eds.), Translating Organizational Change (pp. 13-47). Berlin: Walter de Gruyter. https://doi.org/10.1515/9783110879735.13

Dabbicco, G. (2013). The reconciliation of primary accounting data for government entities and balances according to statistical measures. OECD Journal on Budgeting, 13(1), 31-43. https://doi.org/10.1787/budget-13-5k409g5913xq

Dasí, R. M., Montesinos, V., \& Murgui, S. (2016). Government financial statistics and accounting in Europe: is ESA 2010 improving convergence? Public Money \& Management, 36(3), 165-172. https://doi.org/10.1080/09540962.2016.1133964

Dasí, R. M., Montesinos, V., \& Murgui, S. (2013). Comparative Analysis of Governmental Accounting Diversity in the European Union. Journal of Comparative Policy Analysis: Research and Practice, 15(3), 255-273. https://doi.org/10.1080/13876988.2013.798117

DiMaggio, P. J., \& Powell, W. W. (1983). The Iron Cage Revisited: Institutional Isomorphism and Collective Rationality in Organizational Fields. American Sociological Review, 48(2), 147-160. https://doi.org/10.2307/2095101

Ernst \& Young (2012). Overview and comparison of public accounting and auditing practices in the 27 EU Member States, 19 December.

European Commission (2013). Towards implementing harmonised public sector accounting standards in Member States. The suitability of IPSAS for the Member States. COM(2013) 114 final, Brussels.

Eurostat (2013a). The statistical recording of low interest rate loans. 16 January. 
Eurostat (2013b). EDP dialogue visit to Spain. 30 August.

Giovanelli, L. (2006). Contabilità dello Stato e sistema europeo dei conti (SEC95) nella prospettiva comunitaria. Milano: Giuffrè.

Guthrie, J., \& Humphrey, C. (1996). Public sector financial management developments in Australia and Britain: Trends and contradictions. Research in Governmental and Non-profit Accounting, 9, 283-302.

Hepworth, N. (2003). Preconditions for Successful Implementation of Accrual Accounting in Central Government. Public Money \& Management, 23(1), 37-44. https://doi.org/10.1111/1467-9302.00339

Jacobs, K., \& Cuganesan, S. (2014). Interdisciplinary accounting research in the Public Sector. Accounting, Auditing \& Accountability Journal, 27(8), 1250-1256. https://doi.org/10.1108/AAAJ-06-2014-1732

Jesus, M. A., \& Jorge, S. (2016). Accounting basis adjustments and deficit reliability: Evidence from southern European countries. Revista de Contabilidad - Spanish Accounting Review, 19(1), 77-88. https://doi.org/10.1016/j.rcsar.2015.01.004

Jesus, M. A., \& Jorge, S. (2012). Governmental Accounting versus National Accounts: Implications of different accounting Bases on EU Member-States Central Government deficit/surplus. Working Paper 12/01, Instituto Universitario de Lisboa.

Jorge, S. M., De Jesus, M. A. J., \& Laureano, R. M. (2014). Exploring Determinant Factors of Differences between Governmental Accounting and National Accounts Budgetary Balances in EU Member States. Transylvanian Review of Administrative Sciences, 34-54.

Kanter, R. M. (1972). Commitment and Community. Cambridge: Harvard University Press.

Keuning, S. J., \& Van Tongeren, D. (2004). The Relationship between Government Accounts and National Accounts, with special reference to Netherlands. Review of Income and Wealth, 50(2), 167-179. https://doi.org/10.1111/j.0034-6586.2004.00119.x

Kvaal, E., \& Nobes, C. W. (2010). International differences in IFRS policy choice: a research note. Accounting and Business Research, 40(2), 173-187. https://doi.org/10.1080/00014788.2010.9663390

Kvaal, E., \& Nobes, C. W. (2012). IFRS Policy Changes and the Continuation of National Patterns of IFRS Practice. European Accounting Review, 21(2), 343-371. https://doi.org/10.1080/09638180.2011.611236

Lande, E. (2006). Accrual Accounting in the public sector: Between institutional Competitiveness and the search for Legitimacy. In Accounting Reform in the Public Sector: Mimicry, Fad or Necessity, Lande, E. and Scheid J. C. (eds). Paris: Experts Comptables Media, 19-30.

Lapsley, I., Mussari, R., \& Paulsson, G. (2009). On the adoption of accrual accounting in the public sector: a self-evident and problematic reform. European Accounting Review, 18(4), 719-723. https://doi.org/10.1080/09638180903334960

Lee, K. H. (2016). Government Expenditure Financing, Growth, and Factor Intensity. International Journal of Business and Management, 11(4), 178-193. https://doi.org/10.5539/ijbm.v11n4p178

Liguori, M., \& Steccolini, I. (2014). Accounting, innovation and public-sector change. Translating reforms into change? Critical Perspectives on Accounting, 25(4-5), 319-323. https://doi.org/10.1016/j.cpa.2013.05.001

Lüder, K. G. (2000). National Accounting, Governmental Accounting and Cross-country Comparisons of Government Financial Condition. Financial Accountability \& Management, 16(2), 117-128. https://doi.org/10.1111/1468-0408.00100

Lüder, K. G., \& Jones, R. (2003). The Diffusion of Accrual Accounting and Budgeting in European Countries A Cross-Country Analysis. In Lüder, K. G., and Jones R. (Eds.), Reforming Governmental Accounting and Budgeting in Europe. Frankfurt am Main: Fachverlag Moderne Wirtschafts.

Maingot, M. (2006). The Evolution of the Standard Unqualified Auditor's Report in Canada. Canadian Accounting Perspective, 5(1), 19-36. https://doi.org/10.1506/1ENC-28F8-5NCR-CREX

Martí, C. (2006). Accrual budgeting: Accounting treatment of key public sector items and implications for fiscal policy. Public Budgeting \& Finance, 26(2), 45-65. https://doi.org/10.1111/j.1540-5850.2006.00846.x

McSweeney, B., \& Duncan, S. (1998). Structure or agency? Discourse or meta-narrative? Explaining the emergence of the financial management initiative. Accounting, Auditing \& Accountability Journal, 11(3), 332-361. https://doi.org/10.1108/09513579810224536 
Miller, P. (1994). Accounting as Social and Institutional Practice: An Introduction. In Hopwood, A. \& Miller, P. (Eds.), Accounting as Social and Institutional Practice. Cambridge: University of Cambridge Press.

Modell, S. (2002). Institutional perspectives on cost allocations: integration and extension. European Accounting Review, 11(4), 653-679. https://doi.org/10.1080/0963818022000000993

Montesinos, V., \& Vela, J. M. (2000). Governmental accounting in Spain and the European Monetary Union: A critical perspective. Financial Accountability \& Management, $16(2), \quad 129-150$. https://doi.org/10.1111/1468-0408.00101

Nobes, C. W., \& Parker, R. (2010). Comparative International Accounting. Pearson Prentice Hall.

Olson, O., Guthrie, J., \& Humphrey, C. (eds.) (1998). Global Warning: Debating International Developments in New Public Financial Management. Oslo: Cappelen Akademisk Forlag.

Paivio, A. (1974). Spacing of Repetitions in the Incidental and Intentional Free Recall of Pictures and Words. Journal of Verbal Learning and Verbal Behaviour, 13(5), 497-511. https://doi.org/10.1016/S0022-5371(74)80002-2

Parker, L., \& Gould, G. (1999). Changing public sector accountability: critiquing new directions. Accounting Forum, 23(2), 109-135. https://doi.org/10.1111/1467-6303.00007

Pina, V., Torres, L., \& Acerete, B. (2007). Are ICTs promoting government accountability? A comparative analysis of e-governance developments in 19 OECD countries. Critical Perspectives on Accounting, 18(5), 583-602. https://doi.org/10.1016/j.cpa.2006.01.012

PricewaterhouseCoopers. (2014). Collection of information related to the potential impact, including costs, of implementing accrual accounting in the public sector and technical analysis of the suitability of individual IPSAS standards. Brussels: PricewaterhouseCoopers.

Ronen, J. (2008). To Fair Value or Not to Fair Value: A Broader Perspective. Abacus, 44(2), $181-208$. https://doi.org/10.1111/j.1467-6281.2008.00257.x

Ronen, J. (2012). What Do FAS 157 "Fair Values" Really Measure: Value Or Risk? Accounting Perspectives, 11(3), 149-164. https://doi.org/10.1111/j.1911-3838.2012.00037.x

Scapens, R. W. (1994). Never mind the gap: towards an institutional perspective of management accounting practices. Management Accounting Research, 5(3-4), 301-321. https://doi.org/10.1006/mare.1994.1019

Sforza, V., \& Cimini, R. (2016). Central government accounting harmonization in EU Member States: will EPSAS be enough? Public Money \& Management. https://doi.org/10.1080/09540962.2016.1266191

\section{Copyrights}

Copyright for this article is retained by the author(s), with first publication rights granted to the journal.

This is an open-access article distributed under the terms and conditions of the Creative Commons Attribution license (http://creativecommons.org/licenses/by/4.0/). 